J. Clin. Chem. Clin. Biochem.

Vol. 16, 1978, pp. 1-4

\title{
Isotachophoretic Analysis of Serum for Aspartic Acid, Asparagine, Glutamic Acid and Glutamine
}

\author{
By D. V. Robinson and M. Rimpler \\ Medizinische Hochschule Hannover, Institut für Klinische Biochemie und Physiologische Chemie, Abt. Medizinische \\ Chemie
}

(Received April 7/August 26, 1977)

Summary: Free amino acids and other low molecular weight components were separated from samples of human blood serum by membrane ultrafiltration. The filtrates were analyzed for aspartic acid, asparagine, glutamic acid and glutamine by isotachophoresis, without further treatment. For comparison, analyses were also performed by ionexchange chromatography.

The results of the analyses from both methods are of similar magnitude. General trends were noted in the samples analyzed. The values for aspartic acid and asparagine were lower, by both methods, than normal values. Also, the values, that were determined by isotachophoresis, were generally higher than those obtained from ion-exchange chromatography.

The results are sufficient to demonstrate the applicability of the method to the analysis of the two amino acids and their amides in serum.

\section{Isotachophoretische Analyse von Asparaginsäure, Asparagin, Glutaminsäure und Glutamin im Serum}

Zusammenfassung: Freie Aminosäuren und andere niedermolekulare Bestandteile wurden durch Ultrafiltration von menschlichem Blutserum abgetrennt. Mit Hilfe der Isotachophorese wurde in den Filtraten direkt der Gehalt an Asparaginsäure, Asparagin, Glutaminsäure und Glutamin bestimmt. Vergleichsanalysen wurden mit Hilfe der Ionenaustauschchromatographie durchgefürt.

Die analytischen Ergebnisse beider Methoden haben die gleiche Größenordnung. Die Werte für Asparaginsäure und Asparagin sind nach beiden Methoden niedriger als die Normalwerte. Außerdem sind die isotachophoretisch ermittelten Werte allgemein höher als die durch übliche Aminosäureanalysen erhaltenen Daten.

Durch die Isotachophorese können die zwei genannten Aminosäuren und ihre Amide in einfacher Weise vorteilhaft bestimmt werden.

\section{Introduction}

The occurrence of abnormal levels of aspartic acid, asparagine, glutamic acid or glutamine in the serum and/ or urine of children suffering from various metabolic disorders affecting the nervous system has been noted (1). The analysis of biological fluids for these free amino acids and amides by ionexchange and gas chromatography has been reported. However, both methods present difficulties in the preparation of the samples. The exhaustive deproteinization, that is necessary, often results in the adsorption of certain free amino acids onto the denatured protein precipitate, thereby lowering the values for these amino acids. A high lipid content in the sample also adversely affects the column life and separation in both methods.
Isotachophoresis is tolerant to non-polar impurities as they do not migrate in the electric field and remain at the point of injection. High molecular weight components may be eliminated by prior ultrafiltration. The isotachopherogram is normally simple enough to be interpreted for a limited number of free amino acids. The main restrictions of such an analysis are those imposed by the separating capacity of the buffer system, the length of the capillary and the sensitivity of the detector.

The analysis of amino acids using isotachophoretic apparatus is well documented (2-5) with respect to synthetic mixtures and the hydrolysis products of small synthetic peptides. Also, amino acid spacers have been used in the separation of serum proteins (6). There do 
not appear to be any reported attempts at the analysis of non-ultraviolet-absorbing amino acids in biological fluids.

The mobilities of aspartic acid, asparagine, glutamic acid and glutamine under isotachophoretic separation conditions (7) indicate that the analysis of these amino acids and amides is possible. Any difficulties with regard to separation capacity may be resolved by modification of the buffer system, or by special experimental techniques (8). Minimum detection limits of 1-10 nmol are possible with several detectors at present available $(9,10)$. Detection limits as low as 16 pmol have been reported with highly absorbing ultraviolet species (9). General methods of detection, such as the potential gradient detector, require higher concentrations, on the order of $2.5 \mathrm{nmol}$ or less. The use of an ultraviolet detector for the quantification of nonultraviolet absorbing species has also been reported $(11,12)$.

In an isotachophoretic separation the nature of the leading buffer tends to dominate the analysis (6). In our analytical procedure chloride was chosen as the leading ion due to its high effective mobility (13) and native abundance in serum filtrates. For the separation of aspartic acid, asparagine, glutamic acid and glutamine the optimum $\mathrm{pH}$ of the leading buffer system has been. calculated as $\mathrm{pH}=8.9-9.3(7)$. Additives, such as TRITON X-100 ${ }^{1}$ ) or $\mathrm{HPMC}^{2}$ ), are used as surface active agents to limit electroosmosis (14) and as viscosity modifiers to stabilize the gradient. The terminating buffer system was selected so as to contain a terminating ion with a lower effective mobility than the two amino acids and their amides to be determined (glycine) and to possess a $\mathrm{pH} \geqslant 10$ to prevent the formation of $\mathrm{CO}_{2}$ in the capillary.

\section{Methods and Materials}

Samples of human blood serum were obtained from the Hospital of the Medizinische Hochschule Hannover, from patients with suspected thyroid malfunction. Sample 1A demonstrated normal to slight overactivity upon radioimmunoassay. Sample $2 \mathrm{~A}$ demonstrated normal activity, and sample $10 \mathrm{~A}$ demonstrated pronounced overactivity. $6 \mathrm{ml}$ samples were split into $3 \mathrm{ml}$ portions for deproteinization and analysis for aspartic acid, asparagine, glutamic acid and glutamine by isotachophoresis and ion-exchange chromatography.

The duplicate samples were initially deproteinized by ultrafiltration through a Sartorius type 12136 cellulose acetate membrane (Sartorius-Membranfilter GmbH, 3400 Göttingen, West-Germany). This filtration allows the separation of free amino acids and other low molecular weight components whose size is comparable to those of globular proteins of less than $10^{3}$ (approx.) Daltons. These components are passed through the membrane. Larger proteins, lipids and polysacchiarides are retained by the filter. Failure to deproteinize samples by this means, and deproteinization utilizing only sulfosalicylic acid, resulted in values for aspartic acid and glutamic acid that were $10-20 \%$ lower than those obtained using this procedure.

\footnotetext{
1) TRITON X $100=$ polyethyleneglycol-mono $(p-(1,1,3,3-$ tetramethylbutyl)-phenyl)-ether

2) HPMC = hydroxýpropylmethylcellulose
}

The occurrence of a large glucosamine peak in the ion exchange chromatogram also indicates a considerable amount of easily hydrolyzable polysaccharide or glycoprotein which was not removed by chemical deproteinization. The filtrations were accomplished by placing $3 \mathrm{ml}$ of the serum sample on a $19 \mathrm{~mm}$ diameter section of the cellulose acetate membrane, supported in a special tube constructed of polymethylmethacrylate; this was situated on a stainless steel sieve plate; overlayed by an additional $19 \mathrm{~mm}$ diameter section of polyvinylchloride filter paper (1002 PVC paper, Carl.Schleicher \& Schüll, 3354 Dassel, West-Germany), which is necessary to provide additional support for the membrane under high $g$ forces. The samples were then centrifuged through at $12100 \mathrm{~g}$ in a SS-34 Sorvall fixed angle rotor, (RC2-B refrigerated centrifuge), $2-4^{\circ} \mathrm{C}$, for $40 \mathrm{~min}$. This provides $1 \mathrm{ml}$ of human serum filtrate that is nearly protein free. It was later found that the yield of filtrate and the time required for the centrifugation could be improved by using a Spinco JS-13 (Beckman J-21B refrigerated centrifuge). The swinging-bucket rotor appears to allow more complete utilization of the membrane surface area.

The terminating buffer system was composed of a $20 \mathrm{mmol} / 1$ solution of glycine, adjusted to $\mathrm{pH}=10$ with barium hydroxide to precipitate carbonate. The leading buffer system consisted of $5 \mathrm{mg} / \mathrm{l}$ HPMC (Dow $15,000 \mathrm{cps}$ ) adjusted to $\mathrm{pH}=9$ with Tris- $\mathrm{HCl}(10 \mathrm{mmol} / \mathrm{l} \mathrm{Cl})$. The sample size normally injected inito the capillary was $5 \mu \mathrm{l}$. Runs were made at $102 \mu \mathrm{A}$ in an $81 \mathrm{~cm}$ capillary with a voltage "trip" set at $20 \mathrm{kV}$. After the "trip" was activated the current was reduced to $50 \mu \mathrm{A}$ and the signals from the thermal and ultraviolet detector recorded from an LKB 2127 Tachophor (LKB Produkter, Bromma 1, Sweden). Sweden).

A parallel sample consisting of $0.5 \mathrm{ml}$ predeproteinized human serum filtrate was mixed with $5 \mathrm{mg}$ of sulfosalicylic acid and centrifuged. The supernate was diluted $1: 4$ with lithium-citrate buffer and subjected to ion-exchange chromatographic analysis.

\section{Results and Discussion}

The evaluation of an "isotachopherogram" involves somewhat different procedures than are utilized in chromatograms of the usual type (i.e., gas liquid chromatography, ionexchange, etc.). In conventional chromatographic data the area under the peak in the absorption vs. time curve is directly proportional to the quantity of that component present. In isotachophoresis this is also true for peaks present in the ultraviolet trace, but only for those components whose photometric peak height is linearly proportional to the quantity of the component present (15). This condition is normally only fulfilled when the zone length for the component is less than or equal to the slit-width of the detector (the response time of the detector and complete separation in a given buffer system being taken into consideration). Beyond this amount the zone length is directly proportional to the quantity of component present, up to the saturation point for the system in question. Therefore, one need only measure the distance between two ultraviolet absorbing peaks to determine the quantity of a third non-ultraviolet absorbing peak which occurs between the two.

In a typical "isotachopherogram" for serum filtrate, a total of sixteen ultraviolet absorbing peaks have been found in all samples so far examined in fresh Tris- $\mathrm{HCl}$ buffer. In figure 1, a typical "isotachopherogram" for 


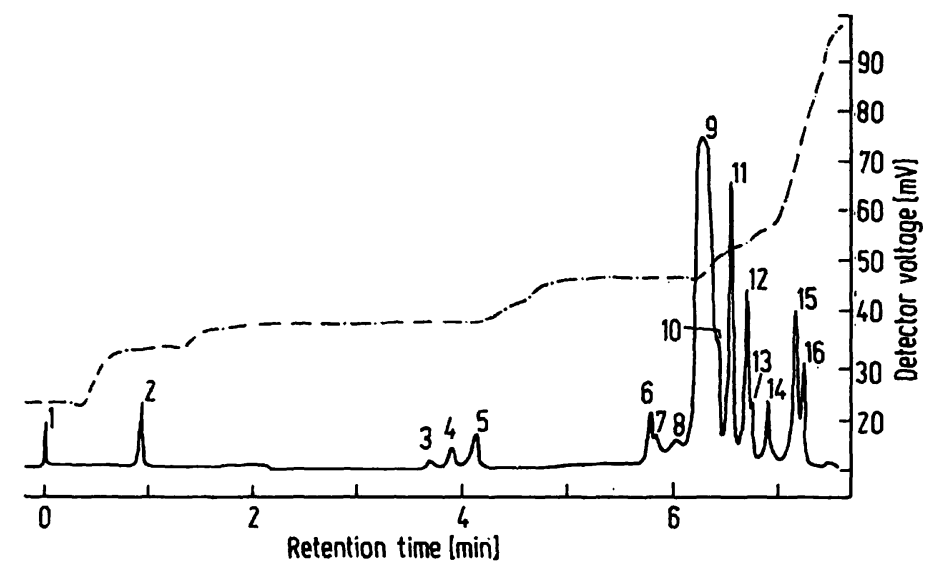

Fig. 1. Chromatogram showing ultraviolet (-) and differential thermal signals (-.-.) for a $5 \mu$ l sample of human blood serum.

a $5 \mu \mathrm{l}$ sample of human serum filtrate is presented. When such a sample was supplemented with varying quantities of Asp, Asn, Gln and Glu there was a linear increase in the distances between peaks 6 and 7,9 and 10,7 and 8 and peaks 14 and 15 respectively, for the two amino acids and their amides mentioned. This relationship was found to be valid when the total volume injected, in the capillary, did not exceed $10 \mu$ l. On this basis the slope of the line, in $\mathrm{nmol} / \mathrm{mm}$ (chart speed $5 \mathrm{~cm} / \mathrm{min}$ ) can be determined. Values of $5.90 \mathrm{nmol} / \mathrm{mm}$ for Glu, $5.76 \mathrm{nmol} /$ $\mathrm{mm}$ for Asp, $14.05 \mathrm{nmol} / \mathrm{mm}$ for Asn and $25.30 \mathrm{nmol} /$ $\mathrm{mm}$ for Gln, were found and the distances present between two peaks in question as found in unsupplemented serum samples can be evaluated. The results of such an evaluation are presented in table 1.

The results of the analysis as presented in table 1 and the isotachopherogram in figure 1 demonstrate several important points. The most important point being that the analysis is performed in less than $40 \mathrm{~min}$ for normal serum samples. The actual analysis portion of the curve taking less than $8 \mathrm{~min}$. This is a marked improvement over conventional ion-exchange chromatography runs under physiological conditions. Asp and Glu present difficulties in both methods as they have a tendency to be adsorbed during the chemical deproteinization required for ion-exchange chromatography; also, owing to their low difference in net mobility, they tend to be lost in the terminating buffer when injected into the capillary under certain circumstances.

With regard to the precision of the isotachophoretic analysis there are several points worth noting. Considerable accuracy may be lost in the method due to the need to concentrate the sample through freeze-drying and redissolving in leading buffer. Better results could be expected if it were possible to use more sensitive detectors and inject serum ultrafiltrates.

Also the extrapolation of $\mathrm{nmol} / \mathrm{mm}$ for supplemented samples to obtain the values of the amino acids present in serum may introduce a systematic error in the interpretation of the isotachopherograms. It appears that calibration of the four amino acids studied against ionexchange chromatographic results for a large number of serum samples may provide higher accuracy. Such a study is currently in preparation.

\section{Acknowledgments}

We wish to express our thanks to LKB, Sweden for the use of the LKB-Tachophor utilized in this investigation and to Mrs. $G$. Juretzka for the fifty and more analytical runs involved in this study.

Tab. 1. Comparison of results from ion-exchange chromatography and isotachophoresis with normal values for human blood serum $(\overline{\mathrm{x}} \pm S D, n=100)$.

\begin{tabular}{|c|c|c|c|c|}
\hline Sample No. & Asp $[\mu \mathrm{mol} / \mathrm{l}]$ & Asn $[\mu \mathrm{mol} / 1]$ & Glu $[\mu \mathrm{mol} / 1]$ & Gln $[\mu \mathrm{mol} / 1]$ \\
\hline $\begin{array}{l}\text { Human Serum } \\
\text { (Normal Value) }\end{array}$ & 150.3 & 90.8 & $\begin{array}{r}17.0-117.6 \\
142.7-259.6\end{array}$ & $\begin{array}{l}273.7-821.1 \\
417.3-697.9\end{array}$ \\
\hline \multicolumn{5}{|l|}{$\begin{array}{l}\text { Ion-Exchange } \\
\text { Chromatography }\end{array}$} \\
\hline $\begin{array}{r}1 \mathrm{~A} \\
2 \mathrm{~A} \\
10 \mathrm{~A}\end{array}$ & $\begin{array}{l}31.5 \\
33.4 \\
40.3\end{array}$ & $\begin{array}{l}38.0 \\
48.0 \\
34.6\end{array}$ & $\begin{array}{r}93.4 \\
102.2 \\
190.9\end{array}$ & $\begin{array}{l}505.2 \\
383.0 \\
417.1\end{array}$ \\
\hline $\begin{array}{l}\text { Isotachophoresis } \\
1 \mathrm{~A} \\
2 \mathrm{~A} \\
10 \mathrm{~A}\end{array}$ & $\begin{array}{l}30.5 \pm 8.0 \\
31.7 \pm 6.0 \\
61.6 \pm 8.6\end{array}$ & $\begin{array}{l}45.9 \pm 6.0 \\
48.0 \pm 7.8 \\
29.5 \pm 5.6\end{array}$ & $\begin{array}{r}68.3 \pm 7.6 \\
153.9 \pm 11.6 \\
197.1 \pm 33.0\end{array}$ & $\begin{array}{l}532.8 \pm 49.7 \\
367.0 \pm 11.4 \\
412.6 \pm 60.7\end{array}$ \\
\hline
\end{tabular}




\section{References}

1. Schafer, I. A. \& Yaffe, S. J.: Amino Acid Metabolism, chapter 94; Menkes, J. H. (1968), Metabolic Disorders, chapter 124, in: The Biologic Basis of Pediatric Practice (Cooke, R. E., ed), The Blakiston Division McGraw-Hill Book Company, New York.

2. Everaerts, F. M. \& Van der Put, A. J. M. (1970), J. Chromatogr. 52, 415-419.

3. Kopwillem, A., Moberg, U., Westin-Sjödahl, G., Lundin, R. \& Sievertsson, H. (1975), Anal. Biochem. 67, 166-181.

4. De Kok, A. J. (1975), Grad. Rep., University of Technology, Eindhoven (Netherlands).

5. Miyazaki, H. \& Katoh, K. (1976), J. Chromatogr. 119, 369-383.

6. Kopivillem, A., Merriman, W. G., Cuddeback, R. M., Smolka, A. J. K. \& Bier, M. (1976), J. Chromatogr. 118, 35-46.
7. Kopwillem, A. \& Lundin, H. (Sept. 1974), LKB Application Note, LKB-Produkter AB, Bromma, Sweden.

8. Everaerts, F. M., Verheggen, Th. P. E. M. \& Van de Venne, J. L. M. (1976), J. Chrómatögr. 123, 139-148.

9. Svoboda, M. \& Vacik, J. (1976), J. Chromatogr. 119, 539-547.

10. Akiyama, J. \& Mizuno, T. (1976), J. Chromatogr. 119, 605-608.

11. Arlinger, L. (Febr. 1974), LKB Application Note, LKBProdukter $\mathrm{AB}$, Bromma, Sweden.

12. Everaerts, F. M. (1972), J. Chromatogr. 65, 3-17.

13. Everaerts, F. M. \& Routs, R. J. (1971), J. Chromatogr. 58, $181-194$

14. Everaerts, F. M. \& Rommers, P. J. (1974), J. Chromatogr. 91, 809-818.

15. Gower, D. C. \& Woledge, R. C. (1977), Science Tools 24, $17-21$.
Prof. Dr. M. Rimpler

Medizinische Hochschule Hannover Abt. Medizinische Chemie Postfach 610180 D-3000 Hannover 61 